\title{
Counsellors in Hong Kong Primary Schools: On Becoming Visible Counselling Professionals
}

\author{
Suk Chun Fung ${ }^{1}$ \\ ${ }^{1}$ Department of Special Education and Counselling, The Education University of Hong Kong, Hong Kong \\ Correspondence: Suk Chun Fung, Department of Special Education and Counselling, The Education University of \\ Hong Kong, Hong Kong, 10 Lo Ping Road, Tai Po, Hong Kong. Tel: 00852-2948-7789. E-mail: fungsc@eduhk.hk
}

Received: August 2, 2019 Accepted: October 8, 2019 Online Published: October 9, 2019

doi:10.5539/gjhs.v11n12p80 URL: https://doi.org/10.5539/gjhs.v11n12p80

\begin{abstract}
This article examines the implications of a new school counselling policy, namely, 'one school social worker for each school', for the professional identity of school counsellors and guidance and counselling services in Hong Kong primary schools. This paper reviews primary school counselling development since the 1970s with a focus on workforce planning. As a result, it identifies two themes: (1) counselling workforce planning has gradually shifted from purely government-led to more school-based planning, and (2) school counsellors with master's-level counselling training qualifications are not adequately recognized in primary school settings. Making school counsellors visible to school principals, the Education Bureau and the public before the full implementation of the new policy in 2021/2022 is critical. The strategic positions of counsellor educators and counselling associations that are central to the advancement of the professional identity of school counsellors are discussed.
\end{abstract}

Keywords: counselling development, one school social worker for each school, school counselling, school counsellor

\section{Introduction}

The tragic and violent death of a five-year-old girl by her family in January 2018 shocked the people in Hong Kong, one of the 37 "advanced economies" in the world (International Monetary Fund, 2015, p. 150). More child abuse cases, including the case of the deceased girl's eight-year-old brother, have subsequently been reported and sparked concern over child protection in Hong Kong. In late February 2018, the Hong Kong government announced that more resources would be provided to primary schools to enhance social work and guidance services. Specifically, the government stated that starting in the 2018/2019 academic year, it would provide an additional expenditure of $\$ 138$ million annually to implement the 'one school social worker for each school' policy in primary schools (Education Bureau Circular Memorandum No. 36/2018, 2018).

Although more funding was invested in guidance and counselling services in primary schools, the new policy was generally criticized by professionals from the counselling, teaching and social work fields. These professionals' high level of concern about the new policy was reflected by the various discussion forums and press conferences held immediately after the policy was announced. Professional associations for counsellors, teachers and social workers, such as the Asian Association of Professional Counselling and Psychology (APCPA), the Hong Kong Professional Counselling Association (HKPCA), the Hong Kong Professional Teachers' Union (HKPTU), and the Hong Kong Social Workers' General Union, expressed their great concern about the new measure by posting their position statements on their websites and sending them to the Education Bureau (EDB) of the Hong Kong government and/or the Education Committee of the Legislative Council (e.g., "The policy 'One school social worker for each school' in primary schools caused controversy. All parties urged the government to implement ' $1+1$ "' https://www.hkptu.org/ptunews/682/headline-s; "Primary school 'One school social worker for each school' policy, eager to do things, not yet optimized first chaos" http://www.hkswgu.org.hk/news_detail.php?id=176) (Hong Kong Professional Teachers' Union Newsletter, 2018; Hong Kong Social Workers' General Union, 2018). In summary, they all expressed that 'one school social worker for each school' should not be the ultimate goal of student guidance and counselling services in primary schools. Furthermore, on May 27, 2018, 11 counselling academics from 7 local universities jointly organized an open forum to react to this new measure. These academics urged the EDB to recognize the professional qualifications of school counsellors and to make "one school social worker and one school counsellor for each school" the ultimate 
goal (Yu et al., 2018). Despite their above actions, none of the university's counselling academics or local professional counselling associations were approached by the government to provide comments and suggestions.

Observing that the policy was implemented in a rush-with the policy announced on February 28, the policy's detailed memorandum circulated among affected schools on April 27, and funding applications closed on May 3 - some counselling academics and counselling associations continued to approach the EDB to reflect their views on the policy. The current paper is an effort to continuously respond to the 'one school social worker for each school' policy, and it has two major goals. First, it aims to identify and discuss the implications of the new policy for the professional identity of school counsellors and guidance and counselling services in Hong Kong primary schools. Second, it aims to discuss how counsellor educators and counselling associations could be strategically positioned to transform the current challenges into opportunities for the development of the counselling profession. Overall, this paper takes a step to continue the discussion on the facilitation of the professional identity of school counsellors in Hong Kong. To accomplish these goals, the paper first describes the development of counselling in Hong Kong primary schools as background information. Then, it examines the workforce planning of primary school counselling before discussing implications of the new policy for the professional identity of school counsellors and the development of primary school counselling. At the end of the paper, strategic actions for counsellor educators and counselling associations are proposed.

\section{Counselling Development in Hong Kong Primary Schools}

\subsection{Stage 1 (1970s and 1980s): External Support of Student Guidance Services by SGOs}

In the 1970s, student guidance service for primary schools was first introduced and provided by the government. The student guidance officers (SGOs) who worked under the Education Department visited primary schools to offer remedial work, that is, individual case work and group guidance activities, to students in need. Each SGO had to serve approximately 3,000 primary students (Lee, 2005; Yuen, 2006; Yuen, Leung, \& Chan, 2014).

\subsection{Stage 2 (1990s to 2001/2002): Whole School Approach to Guidance and Counselling Services by SGOs/SGTs}

The whole school approach to guidance and counselling, which involved all school personnel in providing developmental and preventive guidance services to all students, was formally implemented in 1992 (Yuen et al., 2014). In the same year, the "student guidance teacher (SGT)" post was created to provide school-based guidance services in aided primary schools, while SGOs were responsible for providing school-based guidance services in government primary schools (Education Bureau Circular Memorandum No. 36/2018, 2018). The ratio of SGTs/SGOs to students was 1 to 2500 in 1992 and 1 to 1680 in 1997.

\subsection{Stage 3 (2002/2003 to 2017/2018): Comprehensive Student Guidance Service by SGOs/SGTs/SGPs/NGOs}

Starting in the 2002/2003 school year, the Comprehensive Student Guidance Service (CSGS) was implemented in all primary schools. The CSGS emphasized planned preventive, developmental, and remedial guidance work to support the whole-person development of students (Yuen et al., 2014). The ratio of SGTs/SGOs to students was 1 to 950 during this time period (Yuen, 2006). Additionally, each aided primary school was given the choice of employing an SGT or receiving a grant, namely, the Student Guidance Service (SGS) Grant, to employ student guidance personnel (SGP) or to purchase guidance services from nongovernmental organizations (NGOs). Beginning in the 2012/13 school year, all public sector primary schools with 5 or more classes could receive a Top-up SGS Grant to strengthen the student guidance services.

\subsection{Stage 4 (2018/19 to 2020/21 Transitional Period): Comprehensive Student Guidance Service by SGOs/SGTs/SGPS/NGOs/SSWs}

Starting in the 2018/19 school year, the old funding mode will be gradually replaced by the new funding mode. In other words, SGO and SGT posts or the SGS Grant (SGP post/NGO service) will be gradually replaced by a newly created graduate social worker post in each primary school. According to the policy paper, after a three-year transitional period, all public sector primary schools are required to adopt the 'one school social worker for each school' policy (Education Bureau Circular Memorandum No. 36/2018, 2018). In addition, additional resources will be provided to enhance the support and supervision for school social workers (SSWs) through the Consultation Service Grant (CSG) and to employ extra guidance personnel or purchase various student guidance services from NGOs through a new arrangement with the Top-up Grant.

\section{Workforce Planning in Primary School Counselling}

The above review reveals that the model of guidance and counselling services has shifted from a remedial focus to a comprehensive student guidance service focus. Correspondingly, the staffing ratio of guidance and counselling personnel to students has decreased from 3000 to $2500,1680,950$ and 600 primary students. While the 
development of school guidance and counselling services is on the right track, the workforce planning of guidance and counselling personnel has not caught up with this positive development in terms of clearly defined roles, professional standard entry requirements and resource allocation. A summary of academic and professional entry requirements, in-service training requirements, funding modes and salary ranges for SGOs, SGTs, SGPs, school counsellors and SSWs is shown in Table 1.

During Stages 1 and 2, the positions of SGOs and SGTs were created to provide student guidance and counselling services in primary schools. In-service teachers with a minimum of five years of teaching experience in government and aided primary schools were eligible to apply for these positions. Teachers serving as school guidance personnel is a common practice in neighbouring Asian countries, such as Singapore, South Korea and Taiwan (Guo, Wang, Combs, Lin, \& Johnson, 2013; Kok, 2013; Lee, Suh, Yang, \& Jang, 2012). One of the reasons for hiring teachers as counsellors is the under-provision of local counselling training. In Hong Kong, during these two stages, the only post-degree training for professional counsellors was offered by the Faculty of Education at the Chinese University of Hong Kong. As such, the establishment of the two paraprofessional posts could be regarded as a timely measure to match the on-going development of student guidance and counselling services in primary schools during the late 1900s. For SGOs and SGTs without prior professional training in counselling, different types of on-the-job training were provided by the Education and Manpower Bureau (EMB, the former bureau of EDB). In short, the workforce planning for the provision of counselling services in primary schools was led by the government in Stage 1 and Stage 2. The leading effort could be recognized as a sensible and feasible move in primary school counselling development.

Stage 3 was a critical period of time for the development of CSGSs. In this stage, workforce planning was no longer led by the government. Instead, each aided primary school was given the choice to employ an SGT or receive the SGS Grant. Schools could use the SGS Grant to purchase guidance services from NGOs or to employ an SGP. According to the EDB's Guide on Comprehensive Student Guidance Service (revised in August 2017) (Guide on Comprehensive Student Guidance Service, 2017), "Schools should appoint the following professionals as the supernumerary SGP: Registered teachers with qualifications and experiences in guidance; registered social workers; or professionals in guidance with equivalent qualifications and experiences." In the document, "professionals in guidance with equivalent qualifications" are professionals who possess psychology-related degrees, such as degrees in psychology, educational psychology, clinical psychology, or applied developmental psychology (Guide on Comprehensive Student Guidance Service, 2018). Schools receiving the SGS Grant formulated their annual plans, which included how the grant would be used and how the services would be evaluated. Clearly, school-based workforce planning was employed during Stage 3. As a result, there were various "professionals" with various training backgrounds to take up the SGP posts. There was no in-service training requirement for this post. In addition, according to the EDB's guide on CSGS, "Under the principle of flexible deployment of resources, schools should combine the Top-up Grant with other school resources and re-deploy their resources flexibly to enhance the student guidance service" (Section 3.3.3, Guide on Comprehensive Student Guidance Service, 2018). Under the guideline, primary schools could employ additional personnel to support the student guidance service through the Top-up SGS Grant. The salary of the personnel, which was generally approximately one-third of an SGT's, was the same as that of an untrained subject-matter teaching assistant. The post title varies from school to school, such as "School Counsellor", "Student Counsellor", "Student Support Assistant" and "Teaching Assistant in Discipline and Guidance".

At the same time, nearly all local universities offered master's programmes in counselling in this stage. Accreditation systems for certified counsellors and for accredited postgraduate counselling programmes were established in 2008 and 2011 respectively by the HKPCA. As shown above, the development of master's-level counselling training and accreditation systems for the counselling profession can adequately support better workforce planning for primary school guidance and counselling services. Recent years have witnessed a new phenomenon: an increase in young people with master's-level counselling training working as SGPs hired through the SGS Grant or "School Counsellors" hired through the Top-up SGS Grant. Even though they obtained a master's degree in counselling with supervised counselling practicum experience, they were employed with blurred job descriptions and low rank salary. 
Table 1. A Summary of Academic and Professional Entry Requirements, In-service Training Requirements, Funding Modes and Salary Ranges for SGOs, SGTs, SGPs, School Counsellors and SSWs

\begin{tabular}{|c|c|c|c|c|c|c|c|}
\hline Post Title & & $\begin{array}{l}\text { Student Guidance } \\
\text { Officer (SGO) }\end{array}$ & $\begin{array}{l}\text { Student Guidance } \\
\text { Teacher (SGT) }\end{array}$ & $\begin{array}{l}\text { Student Guidance Personnel } \\
\text { (SGP) }\end{array}$ & $\begin{array}{l}\text { School Counsellor/ } \\
\text { Student Counsellor/ } \\
\text { Student Support } \\
\text { Assistant/ Teaching } \\
\text { Assistant in Discipline } \\
\text { and Guidance }^{\mathrm{a}}\end{array}$ & $\begin{array}{l}\text { School Social Worker } \\
\text { (SSW) }\end{array}$ & $\begin{array}{l}\text { Student Guidance } \\
\text { Personnel }^{\mathrm{a}}\end{array}$ \\
\hline \multirow{4}{*}{$\begin{array}{l}\text { Developmental } \\
\text { Stages of Primary } \\
\text { School } \\
\text { Counselling in } \\
\text { Hong Kong }\end{array}$} & 1 & Post was created & - & - & - & - & - \\
\hline & 2 & Existence & Post was created & - & - & - & - \\
\hline & 3 & Existence & Existence & Post was created & Post was created & - & - \\
\hline & 4 & Existence & Existence & Existence & Existence & Post was created & Post was created \\
\hline Served Schools & & Aided \& government & Aided & Aided & Aided & Aided \& government & Aided \& government \\
\hline Established Post & & Yes & Yes & No & No & Yes & No \\
\hline $\begin{array}{l}\text { Funding Mode and } \\
\text { Budget (monthly } \\
\text { HK\$ in 2018/19 } \\
\text { school year) }\end{array}$ & & $\begin{array}{l}\text { Assistant } \\
\text { Master/Mistress in the } \\
\text { civil servant } \\
\text { establishment; pay } \\
\text { scale points } 25 \text { to } 29\end{array}$ & $\begin{array}{l}\text { Assistant } \\
\text { Master/Mistress in } \\
\text { the teaching staff } \\
\text { establishment; pay } \\
\text { scale points } 25 \text { to } 29\end{array}$ & $\begin{array}{l}\text { Student Guidance Service } \\
\text { Grant: } \\
\text { 5-17 classes: half Grant } \\
(\$ 25316) \\
18-37 \text { classes: full Grant } \\
(\$ 50,632)\end{array}$ & $\begin{array}{l}\text { Top-up Student } \\
\text { Guidance Service Grant: } \\
24 \text { classes: } \$ 10,395 \\
30 \text { classes: } \$ 19,305\end{array}$ & $\begin{array}{l}\text { Assistant Social Work } \\
\text { Officer post, funded by } \\
\text { School Social Work } \\
\text { Service Grant: midpoint } \\
\text { salary of the Assistant } \\
\text { Social Work Officer }\end{array}$ & $\begin{array}{l}\text { Top-up School Social } \\
\text { Work Service Grant: } \\
24 \text { classes: } \$ 19,305 \\
30 \text { classes: } \$ 28,215\end{array}$ \\
\hline $\begin{array}{l}\text { Salary/Salary Range } \\
\text { (monthly HK\$ in } \\
2018 / 19 \text { school year) }\end{array}$ & & 48,540 to 58,345 & 48,540 to 58,345 & $\begin{array}{l}\text { No standard salary, varies } \\
\text { among schools from } \\
\text { approximately } 20,000 \text { to } \\
25,000\end{array}$ & $\begin{array}{l}\text { No standard salary, } \\
\text { varies among schools } \\
\text { from approximately } \\
13,000 \text { to } 18,000\end{array}$ & 50,632 & $\begin{array}{l}\text { No standard salary, } \\
\text { varies among schools } \\
\text { from approximately } \\
13,000 \text { to } 18,000\end{array}$ \\
\hline $\begin{array}{l}\text { Academic Entry } \\
\text { Requirement }\end{array}$ & & $\begin{array}{l}\text { Certificate in } \\
\text { education }\end{array}$ & $\begin{array}{l}\text { Certificate } \\
\text { education }\end{array}$ & $\begin{array}{l}\text { Certificate in } \\
\text { education/diploma in social } \\
\text { work/degree in psychology, } \\
\text { educational psychology, } \\
\text { clinical psychology, applied } \\
\text { developmental psychology, } \\
\text { etc. }\end{array}$ & $\begin{array}{l}\text { Hong Kong diploma of } \\
\text { secondary education }\end{array}$ & Degree in social work & $\begin{array}{l}\text { Certificate in } \\
\text { education/diploma in } \\
\text { social work/certificate in } \\
\text { counselling }\end{array}$ \\
\hline
\end{tabular}




\begin{tabular}{|c|c|c|c|c|c|c|c|}
\hline $\begin{array}{l}\text { Professional } \\
\text { Requirement }\end{array}$ & Entry & $\begin{array}{l}\text { Teacher registration } \\
\text { AND pre-service } \\
\text { training course for } \\
\text { SGTs conducted by } \\
\text { the former Education } \\
\text { Department, the } \\
\text { former Education and } \\
\text { Manpower Bureau or } \\
\text { the Education Bureau; } \\
\text { OR certificate course } \\
\text { on student guidance } \\
\text { for teachers of } \\
\text { primary schools } \\
\text { conducted by a local } \\
\text { tertiary institute or its } \\
\text { equivalent }\end{array}$ & $\begin{array}{l}\text { Teacher registration } \\
\text { AND pre-service } \\
\text { training course for } \\
\text { SGTs conducted by } \\
\text { the former } \\
\text { Education } \\
\text { Department, the } \\
\text { former Education } \\
\text { and Manpower } \\
\text { Bureau or the } \\
\text { Education Bureau; } \\
\text { OR certificate } \\
\text { course on student } \\
\text { guidance for } \\
\text { teachers of primary } \\
\text { schools conducted } \\
\text { by a local tertiary } \\
\text { institute or its } \\
\text { equivalent }\end{array}$ & $\begin{array}{l}\text { Teacher registration with } \\
\text { qualifications and } \\
\text { experiences in } \\
\text { guidance/social worker } \\
\text { registration/“professionals } \\
\text { in guidance with equivalent } \\
\text { qualifications" } \\
\text { (professionals who possess } \\
\text { psychology-related degrees, } \\
\text { such as degrees in } \\
\text { psychology, educational } \\
\text { psychology, clinical } \\
\text { psychology, or applied } \\
\text { developmental psychology) }\end{array}$ & $\begin{array}{l}\text { No specific professional } \\
\text { requirement }\end{array}$ & $\begin{array}{l}\text { Social worker } \\
\text { registration }\end{array}$ & $\begin{array}{l}\text { Teacher registration } \\
\text { with qualifications and } \\
\text { experience in guidance } \\
\text { and/or teaching/social } \\
\text { worker } \\
\text { registration/“other } \\
\text { professionals with } \\
\text { qualifications on } \\
\text { counselling" }\end{array}$ \\
\hline \multicolumn{2}{|c|}{$\begin{array}{l}\text { In-service Training } \\
\text { Requirement }\end{array}$} & Required & Required & Not required & Not required & Not required & Not required \\
\hline
\end{tabular}

${ }^{\mathrm{a}}$ The post title is not official, and it varies from school to school. 
Stage 4 is a three-year period of transition into the new funding mode, namely, the 'one school social worker for each school' policy. After the transition period, the SGO, SGT and SGP positions will be faded out, and only undergraduate-level registered SSWs will remain to take up guidance and counselling work in primary schools. The job description of the SSW is as follows: "being the ex-officio member of the guidance team, plays an important role in the Comprehensive Student Guidance Service (CSGS). Apart from assisting the school in drawing up the student guidance policy and the Annual CSGS Plan, the primary school social worker should also render assistance to the school in implementing student guidance service in the following areas: personal growth education, support service for parents and teachers, and responsive service for students with specific needs. These remedial, preventive and developmental student guidance services include: casework, group work and programmes, consultation and coordination of community resources" (Annex 1: "Appointment of School Social Worker in Primary Schools" at EDB Circular Memorandum No. 36/2018, 27 April 2018). Thus, there is no specific difference in job duties between an SGT/SGP and an SSW. Clearly, regardless of whether the position is SGT, SGP or SSW, the main duty is to implement the CSGS model, which covers four domains of service. The new policy cannot be regarded as an advancement in workforce planning, as it is still a one-man band. Some may argue that primary schools could still use the Top-up Grant to strengthen the workforce. As stated in the EDB official document, schools are encouraged to "implement the "one school social worker for each school" policy according to school-based circumstances" (Education Bureau Circular Memorandum No. 36/2018, 2018). Again, the guidelines (Annex 3: Uses of "School Social Work Service Grant" and "Top-Up Grant" at Education Bureau Circular Memorandum No. 36/2018, 2018) indicate that it is up to the schools to decide whether to employ additional personnel and whether to employ people with different training backgrounds and professional qualifications and experience to assist SSWs. The many options outlined in the guidelines provide schools with great flexibility to spend the Top-up Grant to address their perceived needs. As a result, the aforementioned phenomenon continues.

From the above examination of workforce planning, two themes can be identified. First, workforce planning has shifted from being purely government led in Stages 1 and 2 to adopting a more school-based mode in Stages 3 and 4. Second, formally trained counselling personnel are not adequately recognized in primary school settings. The second theme is likely a logical consequence of the first theme.

\section{Implications for the Professional Status of School Counsellors in Hong Kong}

For decades, counsellors have been invisible in the field of mental health in Hong Kong (Leung \& Lee, 1999; Leung, 2003; Leung, Chan, \& Leahy, 2007; Yu, Fu, Zhao, \& Davey, 2010; Yuen et al., 2014). The professional space has been dominated by other established disciplines, such as social work, educational psychology and clinical psychology (Leung et al., 2007; Yuen et al., 2014). The counselling profession in Hong Kong, which adopts a voluntary, society-based registration (e.g., the Certified Counsellors of the HKPCA), is not included in the occupational structure created by the government. As such, counsellors have very limited career opportunities in the public sector. Additionally, in the study by Yuen et al. (2010), the majority of respondents were not willing to seek counselling, and half of them were not willing to pay for counselling services. Private practice is not a feasible option for most counsellors given the high rent for counselling rooms or offices in Hong Kong. Counsellors have thus far remained invisible in both the public and private sectors.

Under this unfavourable development environment, as observed by Yuen et al. (2014), the counselling profession in Hong Kong is still making progress in its sphere of influence, especially in school counselling. It is possible that, on the one hand, the establishment of the CSGS in 2012/2013 and the establishment of the whole school approach to integrated education for the education of special needs children in 2001/2002 urged the provision of counselling services by professionally trained counsellors; on the other hand, the discretion for workforce planning by primary school authorities in Stage 3 provided some professional space for the counselling profession. Both SGPs and the SGTs have a genuine need to study counselling theories and practices. A master's degree and an accredited status are particularly beneficial to individuals who want to be SGPs in primary schools. Although the SGP post is not attractive in terms of its salary and prospects, it is open to individuals who want to engage in guidance and counselling work but do not have teacher or social worker qualifications. In Hong Kong, there are more than 500 primary schools. The provision of counselling posts in primary schools, to a certain extent, has supported the development of master's programmes in counselling as well as accreditation systems for individual counsellor and counselling programmes over the past two decades in Hong Kong. It is anticipated that in the coming decade, most existing SGTs will have received master-level counselling training, and the SGP posts will be filled by counsellors with higher academic and professional qualifications.

The recent introduction of the new funding mode, however, will probably change the expected prospects of the 
counsellors in the context of primary schools. Starting in 2018/2019 academic year, an extra expenditure of $\$ 138$ million will be expended annually to implement the 'one school social worker for each school' policy in primary schools. Specifically, the new policy guarantees that there is at least one social worker with a bachelor's degree to handle school social work and guidance work in each primary school (Education Bureau Circular Memorandum No. 36/2018, 2018). The SGT and SGP positions in the 3-year transitional period will be replaced by SSWs at every primary school. The only professional space for counsellors in primary schools under the new policy is through the use of the Top-up Grant to employ "other professionals with qualifications on counselling" (Education Bureau Circular Memorandum No. 36/2018, 2018). The space for professionally trained counsellors could easily be identified as limited based on the full description of the usage of the Top-up Grant: "employing additional full-time or part-time school social workers/student guidance personnel to cater for more students in need. The student guidance personnel are required to be registered social workers, registered teachers with qualifications and experience in guidance and/or teaching or other professionals with qualifications on counselling" (Education Bureau Circular Memorandum No. 36/2018, 2018). It is obvious that counsellors face great challenges related to this new policy. The limited professional space of counsellors in primary schools will be narrowed even further if there is no refinement of the new policy. This is an undesirable result not only for the counselling profession but also for the development of primary school guidance and counselling services in Hong Kong.

\section{Implications for Guidance and Counselling Services in Primary Schools}

Doubtlessly, the introduction of the new 'one school social worker for each school' policy marked a new stage in the development of primary school guidance and counselling services in Hong Kong. The EDB claimed that the new measure provides schools with more resources, based on the foundation of CSGS, to ensure that each public sector school would have at least one registered graduate social worker with professional qualifications. SSWs, who are offered established positions with reasonably high salaries, are expected to implement the CSGS in primary schools. However, it is unrealistic for an SSW to do well in all aspects of the CSGS, that is, personal growth education, support services for parents and teachers, casework, group work and programmes for students with specific needs as well as consultation and coordination of community resources. Some may argue that under the SSWSG's Top-up Grant, various student guidance services from NGOs could be purchased or extra guidance personnel could be employed to share the heavy workload of SSWs. However, the workload of coordination, mentoring and quality assurance should not be underestimated. To be sure, the vaguely defined role of SSWs is a hindrance for the development of guidance and counselling services in primary schools. On the other hand, as described in the previous section, those guidance personnel are employed with a low salary, short-term contracts, blurred job descriptions and diverse job titles. It is not difficult to imagine, regardless of what qualifications guidance personnel possess, that the blurring of roles and responsibilities will result in high stress, low job satisfaction (Bardhoshi, Schweinle, \& Duncan, 2014; Wilkerson \& Bellini, 2006), and ultimately turnover intentions (Clemens, Milsom, \& Cashwell, 2009).

It is indeed disappointing to see that under the 'one school social worker for each school' policy, the uses of the SSWSG and Top-up Grant in Stage 4 are basically the same as those of the SGSG and the Top-up Grant in Stage 3. In the absence of workforce planning, the potential of the CSGS will not be fully utilized. It is a pity that the provision of an additional expenditure of $\$ 138$ million annually could not bring a new atmosphere in the contexts of guidance and counselling services in primary schools. However, the new measure also brought 11 counselling academics from 7 local universities together to organize an open forum. This forum was the first collaboration effort of Hong Kong counselling professionals to fight for the professional development of counselling in school contexts. This effort could be regarded as a good move to facilitate guidance and counselling services in primary schools. The move should be accelerated and strengthened by the strategic positions of counsellor educators and counselling associations within Stage 4.

\section{Strategic Positions of Counsellor Educators and Counselling Associations}

In the past half century, school counselling has undergone gradual changes and four developmental stages in Hong Kong primary schools. Before moving to Stage 5, the stage of full implementation of the 'one school social worker for each school' policy, counsellor educators and counselling associations in Hong Kong should formulate their strategic positions to transform the foreseeable challenges into opportunities. As highlighted by Lau and Fung (2008), the mindset and values of government bodies and school administrators could affect the decisions to be made and actions to be taken; thus, they should be convinced of as the rationale behind school guidance and counselling work. The authors emphasized that one of the important issues to be resolved is the use of political resources to enhance school guidance and counselling work (Lau \& Fung, 2008). The school counsellor systems introduced by the Ministry of Education, Culture, Sports, Science and Technology in Japan (Yagi, 2008) and the 
1997 Elementary and Secondary Education Act from the Ministry of Education in South Korea (Lee \& Yang, 2008) are both good examples of political resources provided at the government level. Additionally, in Taiwan, counselling services have experienced rapid growth in the recent decade (Guo et al., 2013). School counselling has entered a new era since the passage of the Psychologist Law (Laws and Regulations Database of the Republic of China, 2001). Licensure systems for counsellors have been established by this legislation (Guo et al., 2013). In the Hong Kong context, there is nothing more important than making school counsellors visible to government officials, school principals, and the public. Counsellor educators and counselling associations should take strategic actions in at least three dimensions.

\subsection{Follow up With Government Officials}

Recognizing the importance of government support, counsellor educators and counselling associations should closely follow up with the EDB, which has promised to review the collaboration mode of student guidance and social work services and explore various feasible options together with members of the profession while implementing the new policy. The follow-up work should be strategic and timely to facilitate the policy review process. Specifically, the proposal should make use of the existing policies and resources and take a step-by-step approach. As a first step, counsellor educators and counselling associations should clearly propose one refinement to the current policy. The proposed refinement is "employing an additional full-time school counsellor to cater to more students in need. The school counsellor is required to be a graduate of a bachelor's-level or master's-level counselling program that is accredited by a local professional counselling association." There are four rationales behind the above proposal. First, the proposal makes use of the existing SSWSG's Top-up Grant. No extra budget is required for the change. Second, the proposal guarantees that one full-time school counsellor will be included in the school context. A one-man band will no longer exist in school guidance and counselling work. Third, the post is formally named school counsellor. The unification of professional terminology is promoted. Finally, the academic and professional qualifications of the post are clearly stated. This ensures that the school counsellor is professionally trained. Counsellor educators and counselling associations should first agree on the above refinement. Then, these entities should take the proposed refinement to the EDB to facilitate the review process within the first half of Stage 4. In promoting this follow-up work, various channels, such as academic papers, newsletter articles, professional seminars and formal meetings with EDB, are necessary.

The next step is the provision of professional input on the workforce planning under the CSGS and the 'one school social worker for each school' policy. A local collaboration model should be developed to allow teachers, social workers, school counsellors and a newly established post, Special Educational Needs Coordinator (SENCO), to converge. The model should include a clear description of the roles and space for all of these professionals to collaborate and exercise their expertise. It is expected that the model could be developed before the end of Stage 4 . Beyond counsellor educators, the involvement of current SGOs, SGTs, SGPs and SSWs is needed to construct the collaboration model. The frontline experiences of these professionals are most valuable to model development. Again, the new collaboration model makes use of the existing CSGS and the 'one school social worker for each school' policy and resources. There is no pressure for the government to make significant policy changes or to increase the large budgets in school counselling work.

\subsection{Seminars for School Principals}

It is suggested that counsellor educators and counselling associations work together to provide school principals with school counselling seminars. In Hong Kong, the public generally believes that social workers are the best equipped professionals to provide counselling services (Leung et al., 2007; Yuen et al., 2014). As Frey and Dupper (2005) stated, many school administrators usually have a narrow understanding of social work. School administrators may perceive social workers to be mental health specialists and may not care about the differences between SSWs and school counsellors with regard to their philosophies or intervention methods. It is necessary to increase school principals' understanding of the strengths of counsellors with regard to psychological interventions and counselling skills. As such, the major goal of seminars is let principals know what counselling is and what counsellors do, especially in the school context.

The attractiveness of seminar topics is critically important. In Hong Kong, which is a fast-moving and fast-changing society, new challenges appear in primary schools. It is very likely that counselling cases relating to child abuse, school bullying and special educational needs (SEN) would attract attention from principals. As mentioned at the very beginning of this paper, a tragic child abuse case aroused public concern over child protection in Hong Kong. It is not unreasonable for the public to query why there were no school interventions for the five-year-old girl and her eight-year-old brother who were seriously abused by their parents. Issues of child abuse have recently received much attention among schools. Another publicly known school issue is the high 
percentage of students who reported being bullied at the 2015 Program for International Student Assessment (PISA). An average of $32.3 \%$ of 15 -year-old Hong Kong students reported that they suffered from any type of bullying act at least a few times a month, whereas the mean in OECD countries was 18.7\% (OECD, 2017). Hong Kong ranked first among 54 Organization for Economic Cooperation and Development (OECD) countries in this respect (OECD, 2017). Similar to Taiwan's situation, school bullying issues have brought the quality of school guidance and counselling services to the attention of the public (Guan, Chan, Zhang, \& Lin, 2011). Counselling interventions for students with SEN have also received increasing attention from principals since 2011. By that year, all 460 primary schools in Hong Kong were requested to adopt a whole school approach to support students with SEN, including those with mild intellectual, physical or sensory disabilities. The inclusion of students with SEN in mainstream schools is challenging. It is not uncommon to find that students with SEN are also victims of school bullying and child abuse.

The presentation of cases should be strategic to highlight the serious consequences of neglecting the counselling needs of vulnerable children. In that sense, real local cases are much more convincing learning material. In addition, a collaboration model of counselling services should be proposed for participating principals. The compulsory element of counselling practicums in an accredited master's-level counselling programme should be highlighted in these seminars. Throughout presentations, the term "school counsellor" should be consistently and frequently used.

\subsection{Promotions to the Public}

The lack of public understanding has long been identified as a major obstacle to the growth of the counselling profession in Hong Kong (Heppner, Casas, Carter, \& Stone, 2000; Leung et al., 2007; Yuen et al., 2010, 2014). People in the counselling field do not seem eager to engage in or familiar with promoting the profession through mass media. In 2015, the HKPCA established the Professional Issue and Advocacy Committee to promote the profession to the public. Recently, the committee produced a two-minute video to disseminate an explanation of what counselling is. The effort, though on the right track, was too little to achieve the purpose of the promotion. A video programme on a series of counselling cases in school contexts is proposed to be produced. Through watching each counselling case, the public could become familiar with the "school counsellor" profession and have an understanding about what school counsellors do. The public image of school counsellors as active listeners and personal growth facilitators is desired. Such a video would be a substantial project. Counselling associations seem to be the right ones to take on the leading role in this promotion work. The collaboration effort of counsellors, counsellor educators and people in the field of mass media is required. Such promotion work is important in increasing the recognition of Hong Kong counselling professionals.

\section{Concluding Remarks}

The newly launched 'one school social worker for each school' policy could be regarded, on the one hand, as a challenge to the professional identity of school counsellors and, on the other hand, as an opportunity for the counselling community to work together to make school counsellors visible to school principals, the public and the EDB. To become a visible counselling profession, counsellor educators and counselling professional associations should engage in strategic and timely actions. The current paper is a follow-up action of the 5/27 (May 27) open forum. Strategic positioning is proposed for references, discussions and actions. It is expected that "school counsellor" will become a formal title with a clear job description in Stage 5 starting in 2021/22. Finally, the school counsellor role should become an established post with the entry requirement of master's-level counselling training qualifications and professional membership to achieve the next stage: "one school social worker and one school counsellor for each school" in Hong Kong.

\section{Competing Interests Statement}

The author declares that there are no competing or potential conflicts of interest.

\section{References}

Bardhoshi, G., Schweinle, A., \& Duncan, K. (2014). Understanding the impact of school factors on school counselor burnout: A mixed-methods study. The Professional Counselor, 4, 426-443. https://doi.org/10.15241/gb.4.5.426

Clemens, E. V., Milsom, A., \& Cashwell, C. S. (2009). Using leader-member exchange theory to examine principal-school counselor relationships, school counselors' roles, job satisfaction, and turnover intentions. Professional School Counseling, 13(2), 75-85. https://doi.org/10.1177/2156759x0901300203
Education Bureau.
(2017).
Guide
Comprehensive
Student
Guidance
Service. Retrieved from 
https://www.edb.gov.hk/attachment/en/teacher/student-guidance-discipline-services/projects-services/sgs/co mprehensive-student-guidance/web_guide_csgs_1718_e.pdf

Education Bureau. (2018). Guide on Comprehensive Student Guidance Service. Retrieved from https://www.edb.gov.hk/attachment/en/teacher/student-guidance-discipline-services/projects-services/sgs/co mprehensive-student-guidance/web_guide_csgs_e.pdf

Education Bureau Circular Memorandum No. 36/2018. (2018). The policy of 'one school social worker for each school' in primary schools. Retrieved from https://applications.edb.gov.hk/circular/upload/EDBCM/EDBCM18036E.pdf

Frey, A. J., \& Dupper, D. R. (2005). A broader conceptual approach to clinical practice for the 21 st century. Children \& Schools, 27(1), 33-44. https://doi.org/10.1093/cs/27.1.33

Guan, W.-Y., Chan, W.-S., Zhang, M.-S., \& Lin, C.-C. (2011). 杜絕校園霸凌增聘 2221 位輔導人員 [Preventing bullying in schools: 2,221 guidance counsellors will be recruited] the China Times. Retrieved from http://life.chinatimes.com/life/11051801/112011011300045.html

Guo, Y.-J., Wang, S.-C., Combs, D. C., Lin, Y.-C., \& Johnson, V. (2013). Professional counseling in Taiwan: Past to future. Journal of Counseling \& Development, 91, 331-335. https://doi.org/10.1002/j.1556-6676.2013.00101.x

Heppner, P. P., Casas, J. M., Carter, J., \& Stone, G. L. (2000). The maturation of counselling psychology: Multifaceted perspectives, 1978-1998. In S. D. Brown \& R. W. Lent (Eds.), Handbook of counselling psychology (pp. 3-49). New York, NY: John Wiley \& Sons.

Hong Kong Professional Teachers' Union Newsletter. (2018). One school social worker for each school' in primary schools caused controversy. All parties urged the government to implement ' $1+1$. Hong Kong professional teachers'union newsletter. Retrieved from https://www.hkptu.org/ptunews/682/headline-s

Hong Kong Social Workers' General Union. (2018). Primary school 'one school social worker for each school' policy, eager to do things, not yet optimized first chaos. Retrieved from http://www.hkswgu.org.hk/news_detail.php?id=176

International Monetary Fund. (2015). Advanced economies list. Washington, DC: World Economic Outlook.

Kok, J. K. (2013). The role of the school counsellor in the Singapore secondary school system. British Journal of Guidance \& Counselling, 41, 530-543. https://doi.org/10.1080/03069885.2013.773286

Lau, P. S., \& Fung, S. C. (2008). School guidance and counseling in an international context: A reaction paper. Asian Journal of Counselling, 15(2), 207-228.

Laws and Regulations Database of the Republic of China. (2001). 心理師法 [Psychologist law]. Retrieved from http://law.moj.gov.tw/LawClass/LawAll.aspx?PCode=L0020098

Lee, B. S. F. (2005). Comprehensive student guidance service in primary schools. Journal of Basic Education, 14(2), 141-144.

Lee, S. M., Suh, S., Yang, E., \& Jang, Y. J. (2012). History, current status, and future prospects of counseling in

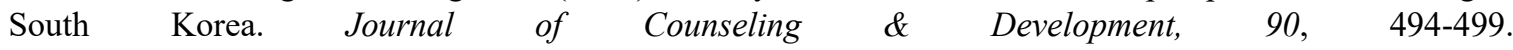
https://doi.org/10.1002/j.1556-6676.2012.00061.x

Lee, S. M., \& Yang, E. (2008). School counseling in South Korea: Historical development, current status, and prospects. Asian Journal of Counselling, 15(2), 157-181.

Leung, S., \& Lee, P. (1999). The development of counselling in Hong Kong: Searching for professional identity. Asian Journal of Counselling, 6(2), 77-95.

Leung, S. A. (2003). Counseling training in Hong Kong: Challenges and possibilities. Asian Journal of Counselling, 10, 235-248.

Leung, S. A., Chan, C. C., \& Leahy, T. (2007). Counseling psychology in Hong Kong: A germinating discipline. Applied Psychology, 56(1), 51-68. https://doi.org/10.1111/j.1464-0597.2007.00275.x

OECD. (2017). PISA 2015 results (Volume III): Students'well-being. Paris, France: PISA, OECD Publishing.

Wilkerson, K., \& Bellini, J. (2006). Intrapersonal and organizational factors associated with burnout among school

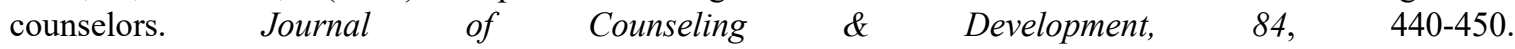
https://doi.org/10.1002/j.1556-6678.2006.tb00428.x 
Yagi, D. T. (2008). Current developments in school counseling in Japan. Asian Journal of Counselling, 15(2), 141-155.

Yu, C. K.-C., Fu, W., Zhao, X., \& Davey, G. (2010). Public understanding of counsellors and counselling in Hong Kong. Asia Pacific Journal of Counselling and Psychotherapy, 1(1), 47-54. https://doi.org/10.1080/21507680903574310

Yu, C. Y. I., Fung, S. C., Fung, L. C. A., Siu, F. Y. A., Tse, S. K. S., Sun, T. L. C., . . Yuen, M. (2018). LegCo members, counselling academics from universities, primary school principals and school counsellors urge for holistic counselling services supported by "one school social worker and one school counsellor for each school". Public forum press release. Hong Kong, China: Hong Kong Shue Yan University.

Yuen, M. (2006). School counselling in Hong Kong: History, policy, current implementation status, and future directions. In C. H. So (Ed.), School counselling and career guidance (pp. 44-70). Macau, MO: Faculty of Education, University of Macau.

Yuen, M., Chan, T. H., Lau, P. S. Y., Yu, L., Chan, R. M. C., Gysbers, N. C., \& Shea, P. M. K. (2010). Implementing the comprehensive guidance and counselling programme in Hong Kong: High school teachers' perspectives. Asian Journal of Counselling, 17(1-2), 61-79.

Yuen, M., Leung, S. A., \& Chan, R. T. H. (2014). Professional counseling in Hong Kong. Journal of Counseling \& Development, 92(1), 99-103. https://doi.org/10.1002/j.1556-6676.2014.00135.x

\section{Copyrights}

Copyright for this article is retained by the author(s), with first publication rights granted to the journal.

This is an open-access article distributed under the terms and conditions of the Creative Commons Attribution license (http://creativecommons.org/licenses/by/4.0/). 